\title{
Article
}

\section{On the Sensory Policing of Vices}

Morality at Work in a German Vice Squad

\author{
Julia Leser \\ Leipzig University
}

\begin{abstract}
This paper explores the policing of vices and offers a critical inquiry into the affective politics of policing practices seen through police and state ethnography, political anthropology, and the 'affective turn' in social and cultural theory. It shows how the moral worlds of policing sex work and performing raids in the red-light 'milieu' are constituted in the making of boundaries through visual, olfactory, somatosensory, and auditory sensations, which can be understood as normative performances in the realm of morality. Police officers do not engage in a neutral gaze but transform the sensuous into sensations that enact these normative distinctions between the 'normal' and the 'abnormal' - the morally questionable red-light 'milieu.' These practices can be read in regard to a morality that is conveyed in and through the officers' sensational performances in an observingly affective and somatic manner. Morality not simply is but is being done - and performing affects and sensations plays a significant role in the making of moral worlds in the realm of policing. Raiding the red-light 'milieu' is a performance on disorder and order, on what is normal and what is not, and thus a deeply political practice that reveals how order- and boundary-making operates through basic sensations and feelings, of the sensuous, the aesthetic, and the somatic.
\end{abstract}

\section{Keywords}

ethnography, policing, sensations, affects, order, sex work, red-light milieu, vices, discretion, morality, practice

\section{Introduction}

On a summer day in July 2015 in a German mid-sized city, shortly after 11 am, an unmarked police car approached the location of a walk-in brothel in the city's industrial area. Detective Chief Superintendent Fuchs and his 10 colleagues just finished the morning meeting at the police station, producing the plan and the schedule for the day's operation, distributing car keys and cars, and finally leaving the station to start the controls. It was a warm and sunny morning when the first 
of the three cars, which included Officer Fuchs, Officer Mueller and me, arrived at the initial 'milieu object' on West Street. Officer Fuchs parked the car in front of a multi-story apartment building in one of the underprivileged neighborhoods of the city. This apartment building was a known address to the officers, it accommodated mostly Bulgarian sex workers who were offering their services, but it also housed a few Thai women. Officer Fuchs and Officer Mueller got out of the car. That day, I was accompanying the officers as part of my ethnographic research with the city's local vice squad. ${ }^{1}$ Wearing a bulletproof vest the officers had provided me with, I was sitting in the back of the police car, and since the rear door could only be opened from the outside, Officer Fuchs had to unlock it to let me out as well. Together, we walked towards the building that had multiple entrances with open doors. There were no signs whatsoever that would indicate that particular services were being offered here, just plain yellowish walls, windows, and a plethora of satellite dishes. The two officers greeted the caretaker, standing in front of the building, in a way that suggested familiarity. Another car arrived with three riot police officers (POs) in it. They joined us. We - at this stage five police officers and me - were entering the building, and the officers started to systematically perform one of the regular control measures in the city's red-light milieu; a practice that was also called a raid.

Officially, the vice squad officers legitimized these raids as a search for evidence of human trafficking. Yet, as I have shown elsewhere (Leser 2018), the vice squad's raids can be understood more broadly as a conglomerate of governmental techniques aimed at policing and control of migrant women engaged in sex work. A raid includes techniques of identification, registration, and classification of 'problematic' subjects, and draws on particular logics of performing control, maintaining order, data acquisition and knowledge production in order to make those subjects of control more manageable.

On that day in July 2015, the police officers went into every apartment of the walk-in brothel on the West Street and checked the passports of every single sex worker they encountered. As the officers systematically inspected one apartment after the other, they eventually entered Mona's apartment on the second floor. Upon entering, Officer Fuchs looked for a place that provided 'some light,' as he

\footnotetext{
1 As a part of the research project Institutionalising Human Trafficking: A French-German Comparison (2014-2017) funded by the DFG (Deutsche Forschungsgemeinschaft) and ANR (Agence nationale de la recherche) and supervised by Rebecca Pates and Mathilde Darley, I conducted ethnographic research within a vice squad police department in a middle-sized German city for six months in 2015 and observed their raids in sex trafficking operations within that period. Both the city and the participants of this study will remain anonymous for ethical reasons-the names of all persons and locations have been changed. The German city that I conducted my research in had about 250.000 inhabitants; the department for sexual offences was about the size of 12 officers. I was spending six months doing intensive ethnographic fieldwork within this police department, and I was spending another six months doing particular observations on certain days, for example for round table meetings or at an anti-prostitution congress. I further accompanied the vice squad officers to press conferences and met with them at the police station to discuss current and ongoing investigations, complementing my field protocols with 25 qualitative semi-structured interviews with various policing agents, administrative officials, and social workers who work in specialised counselling centres for 'victims of human trafficking.'
} 
said, because it was always 'so dark' in these apartments. In all the places controlled by the team during the raids, from brothels to apartments of sex workers, Officer Fuchs, carrying a clipboard with forms and responsible for writing down relevant data, always looked for a place that provided some light to see better what he was writing down. Most of the sex workers' apartments on West Street had a kitchen, a bathroom, a living room, and a working room. The living room in Mona's apartment, as in most cases, was furnished in a more personal way, as the working room was in a professional manner. Fuchs was looking around and breathing in through his nose audibly. He wrinkled his nose and said that it smelled 'horrible' in here. The riot police officer suggested opening a window to let in some fresh air, and Officer Mueller replied, 'Why? So that flies would come in?' He took a moment - as to take it all in - and then expressed in a sarcastic tone, 'This is how Joe Public would imagine the red-light milieu, just like he knows it from TV.' The officers laughed at Mueller's remark. Officer Fuchs meanwhile started to write down the personal data of Mona on one of his control sheets, standing near a window in the kitchen. As Mona placidly intended to light a cigarette, waiting for the officers to finish their routine, Fuchs snapped at her that she should, 'please,' refrain from smoking right now.

As I was accompanying the vice squad officers on their raids in a German city over the course of six months in 2015, I started to notice that they continuously expressed particular reactions to certain stimuli they perceived in a sensuous manner. They did not only articulate how they felt about them, but also performed particular bodily reactions and behaviors. At first, this did not seem relevant to me, but as these instances kept repeating during my observations, it became apparent that these articulated perceptions of and expressed reactions to certain stimuli followed a pattern. They revealed something crucial about the relation between the vice squad and the red-light 'milieu' and its inhabitants, the sex workers.

Sensations are something so basic to people's everyday experiences that they do not appear as a matter that needs to be paid attention to in regard to questions of order and politics, of morality and security. But is this really so? What do the things we feel, smell, taste, see, and hear have to do with the practices of boundary-making, ordering, othering, moralizing or realizing? First and foremost, 'a sensation is how a body is in contact with a world,' and as such, it 'is not an organized or intentional response to something' (Ahmed 2017, 22). Yet this state changes when sensations become a matter of articulation and/or performance. In particular, the articulation of sensations that are perceived as negative, bad, funny, weird, or 'horrible' - as in the case of Officer Fuchs' reaction to the odor of a sex worker's apartment - in most cases implies that the sensuous experience in question is different to the experiences one is used to. Or, more precisely, the sensuous experience is perceived as not normal. Then, a sensation turns into something sensational.

This paper illustrates that the 'moral worlds' (Fassin 2018, 177) of policing sex work and performing raids in the red-light 'milieu' are constituted in the making of boundaries through visual, olfactory, somatosensory, and auditory sensations 
that apply to normative performances in the realm of morality. Police officers do not engage in a neutral gaze but transform the sensuous into sensations that enact the normative distinctions between the 'normal' and the 'abnormal,' morally questionable 'milieu.' These practices can be read in regard to a morality that is conveyed in and through the officers' sensational performances in an observingly affective and somatic manner. Morality not simply is but is being done - and performing affects and sensations do play a significant role in the making of moral worlds in the realm of policing. Raiding the red-light 'milieu,' as I will show in this paper, is a performance on disorder and order, on what is normal and what is not, and thus a deeply political set of practices and processes that explains how orderand boundary-making operates on the grounds of basic sensations and feelings, of the sensuous, the aesthetic, and the somatic.

\section{The 'Turn to Affect' in Studying the Intersections of State, Policing, and Morality}

What we have learned from mainstream theories of the modern state is that the idea of rationality is inherent to it. The rationalization of administration through its detachment from emotions ensures impartiality and establishes the legitimate rule of state bureaucracies, according to the Weberian narrative. Until today, the dichotomy of rationality and emotionality persists (Illouz \& Finkelman 2009), and affects have been largely disregarded by both political theory (Sauer 1999) and political anthropology (Laszczkowski \& Reeves 2015). There are, of course, exceptions: Hochschild's The Managed Heart (1983) has become a canonical work that explores the invasion of rationality into emotional domains, coining the terms 'emotional labour' and 'feeling rules.' But in general it seems that 'the dominant line of reception from Weber, Durkheim and Marxism via Parsons and Habermas, but also Foucault or Bourdieu, has been a systematically anti-affective one [... which] is related to an identification of modernity with rationality and with overcoming the affects' (Reckwitz 2012, 243).

However, in contrast to the orthodox Weberian interpretation of the modern bureaucrat who is free of personal feelings and moral judgements, Du Gay (1994), among others argued that this understanding of bureaucratic rationality needs to be 'unpacked.' Herzfeld (1998) highlighted the indifference and hostility of bureaucrats and thus shed light on the realm of bureaucracy using affects as analytical tools. Scholars have emphasized the interwovenness of rationality and affects in regard to the logics of organizations and bureaucracies (e.g. Fineman 2000), in particular in relation to the emotion management techniques that bureaucrats use to manipulate a client (e.g. Graham 2002; Penz \& Sauer 2016). Stoler (2007) argued that states are inherently affective, and Navaro-Yashin $(2012,31)$ observed that institutions and administrations, modes of governance, and legal practices [are] capable of inducing, and being charged with, affect.' Fassin argued that '[i]n addition to legal and organizational rationalities usually invoked to account for their [the bureaucrats'] activity, there also exist judgements and feelings which underlie them. The police are no exception' $(2015,94)$. 
However, only few attempts have been made to research affects and emotions in policing practices. Loyens (2015) and Mainsant (2010) considered, in developing a state ethnographic approach in the tradition of Lipsky's 'street-level bureaucrats' (1980), how police officers developed certain strategies to cope with emotionally challenging situations. In his edited volume At the Heart of the State, Fassin (2015) examined the moral framework of police officers' practices that justifies interventions against populations deemed 'dangerous' or 'unwanted.' There is only a handful of authors who have explored the moral dimensions of policing practice (Fassin 2015, 2018; Herbert 1996; Johnson 2010, 2012; Muir 1977), and as Fassin noted, the word 'moral' 'is certainly not the adjective most commonly associated with the idea of law enforcement' (2015, 93). Recently, Fassin (2018) conceptualized the moral dimensions and 'moral worlds' of the police profession.

Still, the domain of affects and 'moral sentiments' (Throop 2012) in policing practices appears under-researched, although it holds the potential for developing concepts that could further our understanding of the affective constellations of state practices such as policing. This article offers a critical inquiry into the affective politics of policing practices through the lenses of police and state ethnography, of political anthropology, and of the 'affective turn' in social and cultural theory (Clough 2007; Gregg and Seigworth 2010). The actions of officers are analyzed in the light of the practical workings of governance, and the ways in which 'the state' is performed in everyday routines of state agents. 'The state', here, is regarded as performed (Passoth \& Rowland 2010), and as an effect of practices (Mitchell 1991). Focusing on the discretionary practices of vice squad police officers, I argue that affective politics are deeply enmeshed with the project of governing a particular population, and that affects are a significant part of the state's performativity in regard to social problems.

\section{Affective Politics of Order-making in the Realm of Police Discretion}

The police are usually regarded as an institution that produces, maintains, and defines order and security. Reiner summed up this common assumption in the following way: 'the police are a functional prerequisite of social order so that without a police force chaos would ensue' $(2010,3)$. Despite the institutional novelty and short history of the police, its institutional form maintains the capacity of ordermaking and security-keeping - i.e., the police as a carrier of the state's monopoly of legitimate force - and has become a certainty that is not challenged. However, this assumption tends to overlook the inherent politics of policing projects. Early sociological and ethnographic studies on policing have repeatedly shown that the police role is more complex and more fragmented than what the term law enforcement is able to capture (Banton 1964; Bittner 1974; Skolnick 1966), ${ }^{2}$ and that police officers have 'substantial discretionary power' (Ericson 1982, 202). In his

2 For detailed and comprehensive discussions on ethnographic studies of policing, especially the seminal police ethnographies from the 1960s and 1970s, see Manning (2014) and Reiner (2015). 
observations of the police institution, Bittner $(1967,715)$ has characterized the work of the patrol officer as 'playing by ear' as 'he is making his decisions while being attuned to the realities of complex situations about which he has immensely detailed knowledge.' This concerns the police officer's sphere of discretion, i.e., the sphere between the law and its application (Lipsky 1980), or, according to Skolnick (1966), the space an officer moves within before he puts anything into writing. This discretionary realm is not only guided by informal rules (Bierschenk 2016, 156) and informal norms (Skolnick 1966, 15) - that are often contentious with formal rules and principles - but it is further a space in which the 'politics of policing' (Reiner 2010) become manifest. For the discretion of officers allows them to choose what to order and what to leave unordered, to decide who to suspect and who to trust, and to 'decide who to arrest and whose behavior to overlook' (Lipsky 1980, 13). The discretionary realm is decidedly political. Many recent ethnographic studies on police discretion have investigated how police officers make their decisions and how these inevitably include the making of distinctions and boundaries (e.g. Beek 2012, 2016; Fassin 2013, 2015; Kyed \& Albrecht 2015; Schneider 2014). For instance, Beek has argued that police practices can essentially be examined in terms of 'boundary work and boundary shifting' $(2012,554)$. The boundaries that constitute the order the police are dealing with are thus constantly 'at work,' as Kyed and Albrecht emphasize,

[...] boundary-work is central to policing, and is directly related to its relational dimensions. Policing actors are continuously preoccupied with enacting and negotiating boundaries, not only of particular territorial spaces and populations, but also between order and disorder, right and wrong, and between who is a criminal and who is not [...]. The boundary-work of policing does not always explicitly challenge any one particular order or body of rules, but it is integral to continuous ways of making and unmaking rules and categories (Kyed \& Albrecht 2015, 15-6).

As I argue in this paper, the distinctions and boundaries police officers draw within the discretionary realm, and the decisions they make that rest upon their 'intuitive grasp of situational exigencies' (Bittner 1970, 46), cannot solely be conceived as rational, objective or neutral. The discretionary realm of police officers is affected by their senses in particular situations, their (gut) feelings (Leser et al. 2017), their normative ideas about social morality (Fassin 2018; Johnson 2010; Reiner 2010), and their moral experiences - which, according to Throop, are 'through and through, sentiment-based affairs' and structured by 'the ways we are conditioned to move, balance, see, touch, hear, taste, and smell, to feel particular emotions, sentiments, motives, and moods' (Throop 2012, 158).

Thus, if institutions do not only think, but 'likewise judge and feel' (Fassin 2018, 177), and if the discretionary realm of police officers allows them to do so, we need to consider the order- and boundary-making properties of affects and 'affective practices' (Wetherell 2012). In this regard, the 'turn to affect' in the cultural 
and social sciences provides relevant conceptual devices. As Sara Ahmed argued in The Cultural Politics of Emotion (2004), affects play a crucial role in the making and distinguishing of worlds. Drawing on the philosophy of Judith Butler (1993), Ahmed suggests that different worlds and bodies do not only materialize through the discursive repetition of norms but additionally through affective dynamics in which 'subjects become invested in particular structures ... emotions show us how power shapes the very surface of bodies as well as worlds' (Ahmed 2004, 12). Ahmed understands emotions, in particular fear, hate, pain, and disgust, 'as a form of cultural politics or world making' (ibid.). Understood in this manner, affects are a central, though largely neglected, force in regard to the politics of boundaryand order-making.

Drawing on Ahmed's ideas, policing practices in the discretionary realm can be understood as a matter of affective and sensory politics. In my ethnographic observations of the raids conducted by the local vice squad in a German city, boundary-making took the form of spontaneous and situational performances of feelings and sensations, i.e., of things the officers saw, smelled, or felt and that consequently became the topic of a normative enactment. Through and in these practices, and in these interactions between the vice squad officers and their objects of control, the 'moral world' (Fassin 2018, 177) of the red-light 'milieu' was continuously at work, and normative distinctions were drawn between 'right' and 'wrong', 'normal' and 'deviant', and 'above and below' - as Ahmed puts it,

Lower regions of the body - that which is below - are clearly associated both with sexuality and with 'the waste' that is literally expelled by the body. It is not that what is low is necessarily disgusting, nor is sexuality necessarily disgusting. Lowness becomes associated with lower regions of the body as it becomes associated with other bodies and other spaces. The spatial distinction of 'above' from 'below' functions metaphorically to separate one body from another, as well as to differentiate between higher and lower bodies, or more and less advanced bodies. As a result, disgust at 'that which is below' functions to maintain the power relations between above and below, through which 'aboveness' and 'belowness' become properties of particular bodies, objects and spaces (Ahmed 2004, 89).

The affective politics of policing, and the 'moral worlds' the officers engage in making and maintaining, are decidedly particular and historically embedded when it comes to the policing of sex and sex work. In this regard, Johnson $(2012,32)$ has shown that 'police officers are understood to occupy a particular standpoint in respect of sexual morality' - a standpoint that 'is aligned with socially normative ideas about sex and sexuality.' The relation between the police and sex work has been shaped and formed over time. Within the (short) genealogy of the police institution, its development and differentiation, the attendance to the problem of prostitution has always been a focal point. As criminal police departments within 
major German cities professionalized and specialized around the turn of the 20th century (Gross et al. 2008, 13), differentiated institutions of the criminal police evolved according to the localization and the exclusive policing of particular fields of crime. Among these specialized criminal police departments, the Sittenpolizei (morality or vice squad) was assigned to policing prostitution. In the European context, historians and sociologists have shown how this particular relationship between prostitution and its governance has been shaped by discourses and ideas about the norms and normativities of sex and sexuality (e.g. Agustín 2008b; Walkowitz 1980). In this regard, Agustín argued that ' $[t]$ he word prostitution is neither a precise job description nor the designation of unequivocal or definite acts but rather an idea loaded with ambiguities and moral judgements' (2008a, 73). As Foucault has shown in The History of Sexuality (1976), sex became a discursive object inseparably intertwined with power and knowledge in the emerging field of science that was taking an increasing interest in those kinds of sexualities that were considered 'perverse' or 'abnormal' during the $18^{\text {th }}$ and $19^{\text {th }}$ centuries. In this context and time, '[t]he formation of the modern state and developments in medical and social science meant that prostitution was increasingly cast as a "distinctive" bio-political problem' (Scoular 2015, 31).

Still, the relation between the world of the vice squad and the world of vice, a.k.a. the 'milieu,' pertains to a normative order that is actively shaped by the everyday work practices of the vice squad. In the practice of the raid, two co-dependent and co-constitutive worlds are continually 'at work,' the vice squad on the one hand and its 'shadowy but constitutive Other' - the world of vices, the 'milieu'on the other (Valverde 2003, 16). The raid as a 'traditional' practice employed in vice squad policing (Farrell \& Pfeffer 2014), as I will demonstrate, is not a mere technical or rational procedure of law enforcement, but also a performance on disorder and order, on what is normal and what is not, and thus a deeply political set of practices and processes that reveals how order- and boundary-making operates on the grounds of basic sensations and feelings - as, in Ahmed's words, "aboveness" and "belowness" become properties of particular bodies, objects and spaces' (Ahmed 2004, 89).

\section{Boundary-making Through Sensations}

'Milieu,' as the vice squad officers were using the term, was like a biotope where offences and crime flourish. It formed an 'outside' to the world of their department. The 'milieu' had to be met with police forces and measures of control because, to them, it was inherently disorderly and dubious. To the officers, it was a blind spot in the state's vision, and an obnoxious stain in the city's social fabric. The officers were using the term 'milieu' as if to refer to another world - a somehow strange underworld that had its own rules and a particular kind of inhabitants - a world that was hidden, dark, clandestine, and potentially dangerous. The 'milieu' was positioned within what Manning (2003, 212) calls a 'moral topography of a city' that was constituted through the officers' 'mental partitioning of space, differentiated into "good" and "bad" areas.' During the raids, the vice 
squad officers not only came into touch with the 'milieu,' but the boundaries between the two moral worlds - the vice squad and the world of vices - were made visible and tangible. In taking a closer look at the ethnographic material, four dimensions of 'boundary-making through sensations' can be distinguished: visual, olfactory, somatosensory, and auditory.

The first dimension, that of vision and the visual, constituted the underpinning principle of the raid. In my first meeting with city Y's vice squad in February 2015, Officer Fuchs explained the objective of the raid in the following manner: 'In performing our controls regularly, we make an effort to keep an overview [...].' More precisely, he instructed the riot POs at the beginning of the raid with the words, 'As soon as we're in the apartment, the first thing we do is securing the status quo. That means, we'll have a look into all of the rooms.' The desire for making the unknown known is innately tied to the matter of visibility, of vision, and of making something visible. This is why the first thing the officers did upon entering a sex worker's apartment or a brothel was having a look around.

In a brothel. Officer Grohl goes straight behind the bar, shines his flashlight in every corner, proceeds doing that in the room behind the bar, and reappears a few moments later with a piece of paper in his hands that he obviously found in the back room. Grohl asks Fuchs, 'Here, these are records with amounts of money. Do you want to take a picture?' Fuchs says, 'No.' After a while, the officers proceed to the upper floor. There are five or six rooms. Grohl goes into one room, comes out, goes into the next, and, in this manner, is having a look at all of these rooms. The riot PO Schneider comes up the stairs. He asks me if we already had a look into all of these rooms. Grohl comes out of the last room, wrinkles his nose, and says, 'Woah, this is so nasty (field notes, 2015).

During the initial procedure of 'having a look around,' it was in most cases the darkness that the officers complained about and tried to avoid, although it was never so dark as to conceal certain items that attracted the attention of the officers. What they saw and what entered their field of vision was frequently a matter that the officers deemed necessary to point out either to the present sex workers or to their colleagues. The former often received admonishing and condescending comments in regard to their indecent dress or their 'sloppiness.' While with the latter they shared impressions and joked around.

The officers are standing in Monica's apartment. Officer Grohl is looking around.

Grohl: '[addressing Monica] You could do some cleaning.'

Monica: 'Yes.' 
Julia Leser - On the Sensory Policing of Vices

Grohl: 'Now, no clients, so, time to clean.'

Monica: 'I did.'

Fuchs: 'When? Last week?'

Monica: 'Just now.'

Schneider: 'Just now? Sure.'

Grohl: 'No no no, here, the toilet is still dirty. See?'

Another apartment. The officers are standing in the kitchen. Officer Grohl and Officer Fuchs are eyeballing the room, the furniture, and the food on the stove and are mocking the perceived state of disorder.

Fuchs: '[ironically] This is the dream of every housewife or actually every woman. Isn't it nice! Aah, delicious!'

Grohl: 'But with your cold, you can't smell that much, can you?'

Fuchs: 'Well I can smell that!'

Grohl laughs. Fuchs is blowing his nose.

Fuchs: 'I'm looking for a trash bin to throw my hankie in, but it doesn't seem to matter where I'll throw it, if I look at the mess in here' (field notes, 2015).

The officers did not just see and perceive the world they were entering, but they turned raw impressions into expressions of normativity, and sensuous impressions into sensations. These recurring expressions-as-performances conveyed certain moral judgements about the 'milieu' and its inhabitants (e.g. uncleanliness, dirtiness, disorder, or indecency) that the officers pointed out and emphasized in their interactions, as a matter to joke about, to blame the sex workers, or to pity them. However, what these expressions and enactments of seemingly basic sensations also did was to establish the relationship of order between the vice squad officers and the sex workers. This practice took the form of an asymmetrical power relation. In essence, these interactions were about policemen telling women to clean their apartments and put some clothes on. In combination with the officers shining their flashlights and trying to illuminate 'darkness,' their articulations of visual sensations could be read as a control technique that established a difference, a boundary, and a hierarchy and that enacted relations of status and power. 


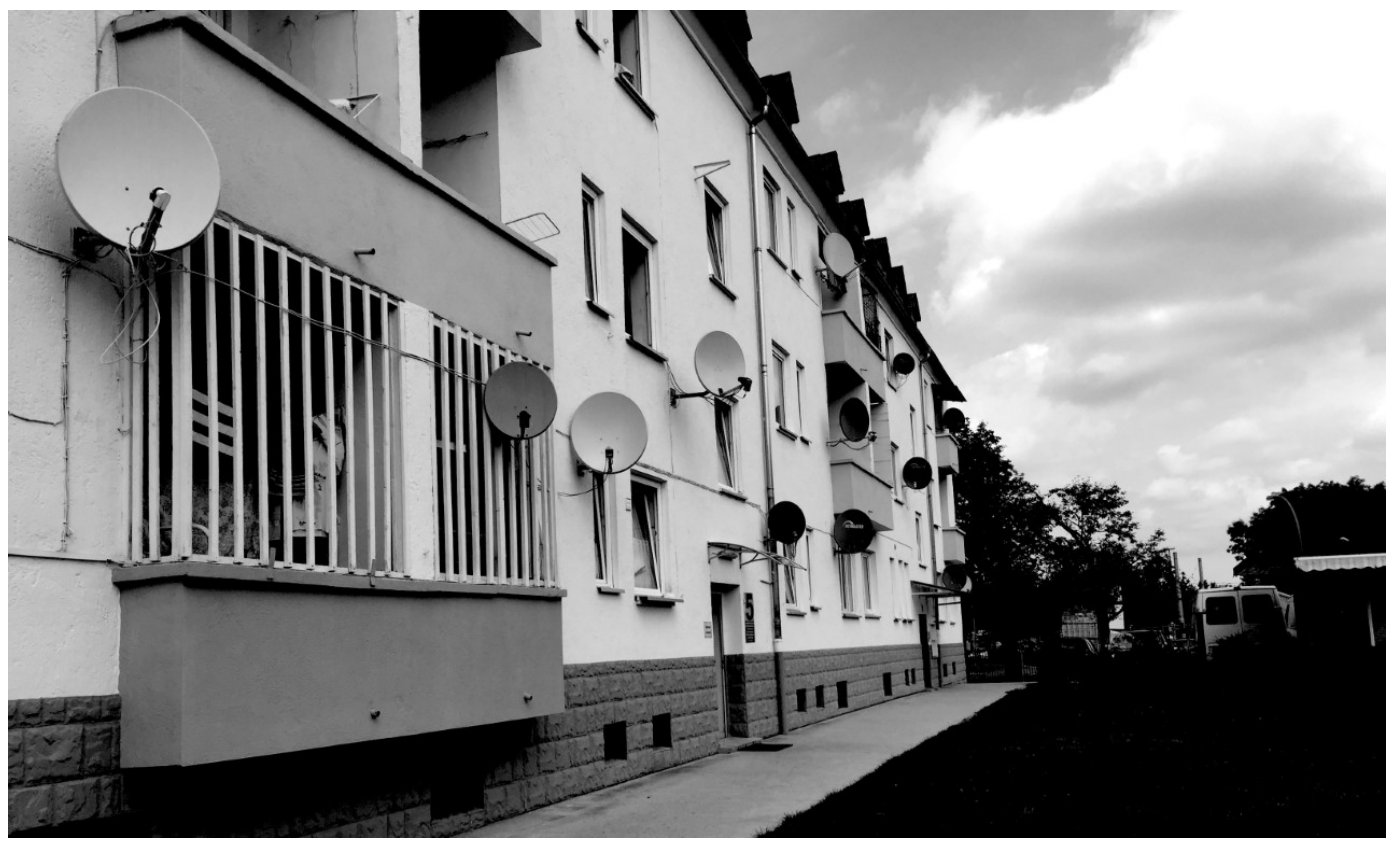

Fig. 1 Outside of a walk-in brothel, Germany, image by author, 2015.

Boundary-making sensations were not only occurring in the dimension of the visual, but also in olfactory, somatosensory, and auditory dimensions:

We arrived in front of a walk-in brothel. After the officers were finished writing down the number plates of every parked car in front of the building in their form sheets, and after they took a picture of every car with their camera (this takes a few minutes), we entered the building through the entrance door that was closest to us (there are three entrances to the building) and rang the doorbell to the first apartment on the ground floor. A Thai woman opened the door and greeted all the entering policemen with a friendly sounding 'hello.' Officer Fuchs asked her, 'Do you have your ID?' Passport?' She replied, 'Yes, one moment, please.' She was in her 50s, wearing casual working clothes. She went into another room to get her passport. Meanwhile, Officer Grohl and Officer Schneider were having a look in all of the rooms.

Grohl: 'Is anybody else here?'

Fuchs: 'If he's not standing behind the door, then no.'

In of the rooms, there was a TV and next to it another screen showing the stream of a surveillance camera installed outside above the apartment door. In a wide-angle shot, the staircase was visible.

Fuchs: 'So, concerning the crystal meth: sometimes it is lying around in a bowl or on the ground, so pay attention.' 


\section{Julia Leser - On the Sensory Policing of Vices}

The officers were looking in the bowls standing around and inspecting the floor. The apartment was cut in a weird way; there were a lot of rooms, and it was difficult to oversee it all. In addition, the apartment was fully furnished, generously decorated, and scattered with an abundance of all kinds of things. The woman was living here permanently, I figure, as opposed to the majority of sex workers who were renting a furnished apartment for a week and then moving on to a different city.

Schneider: 'Thousands of doors, here.'

Officer Schneider and Officer Grohl were, again, not containing themselves in commenting the state of the apartment regarding cleanliness and odor, saying that they 'don't want to touch anything' etc. The woman returned with her passport, and Fuchs copied the data. He asked her for her name and pseudonym, surprised by her year of birth ('1958!'), and then he said, 'That's a really long name.' Slowly reading out loud the syllables of her name from the passport, he wrote it down into the form sheet. Her pseudonym, however, was much shorter: 'Lola' (field notes, 2015).

The field notes above exemplify that the officers were bothered by odors that they, again, did not simply perceive during raiding apartments but accentuated either through an articulation or a demonstrative bodily reaction, e.g. nose-wrinkling. Corporeal performances were enacted in regard to the sensation of touch, too. The officers suggestively avoided 'milieu'-to-skin-contact on numerous occasions, including the covering of their hands with shirt sleeves or using rubber gloves. The officers' refraining from touch was distance-creating, stabilizing and reinforcing boundaries. They also reacted to temperature in the same demonstrative manner as they did to odors and sight. Many of the sex workers' apartments were judged as too warm; the officers would complain that the heating was turned up too high, and sometimes they admonished the women to turn the heating off. The warm temperatures suited the women in lingerie but were bothersome to the fully dressed policemen in leather jackets. In reaction to noise, the officers often commented on the barking of dogs that belonged to the sex workers, avoiding them as well as hushing them up.

The sight and odor of the 'milieu' were enacted as unruly, their inhabitants constituted as out-of-the-norm, their apartments as too warm, and their dogs as too loud. The constitution of the 'milieu' through boundary-making practices of sensations was aligned with the moral standards of the officers - moral standards that were made visible and present through the performances of what was right and what was wrong, what did not smell right, what did not look proper, and what should not be touched. The boundary-making therefore moved within a sphere of morality; the sensuous that was turned into sensation-performed by the officers - was coding morality regarding acceptable forms of sexuality and the proper behavior of women in society. 


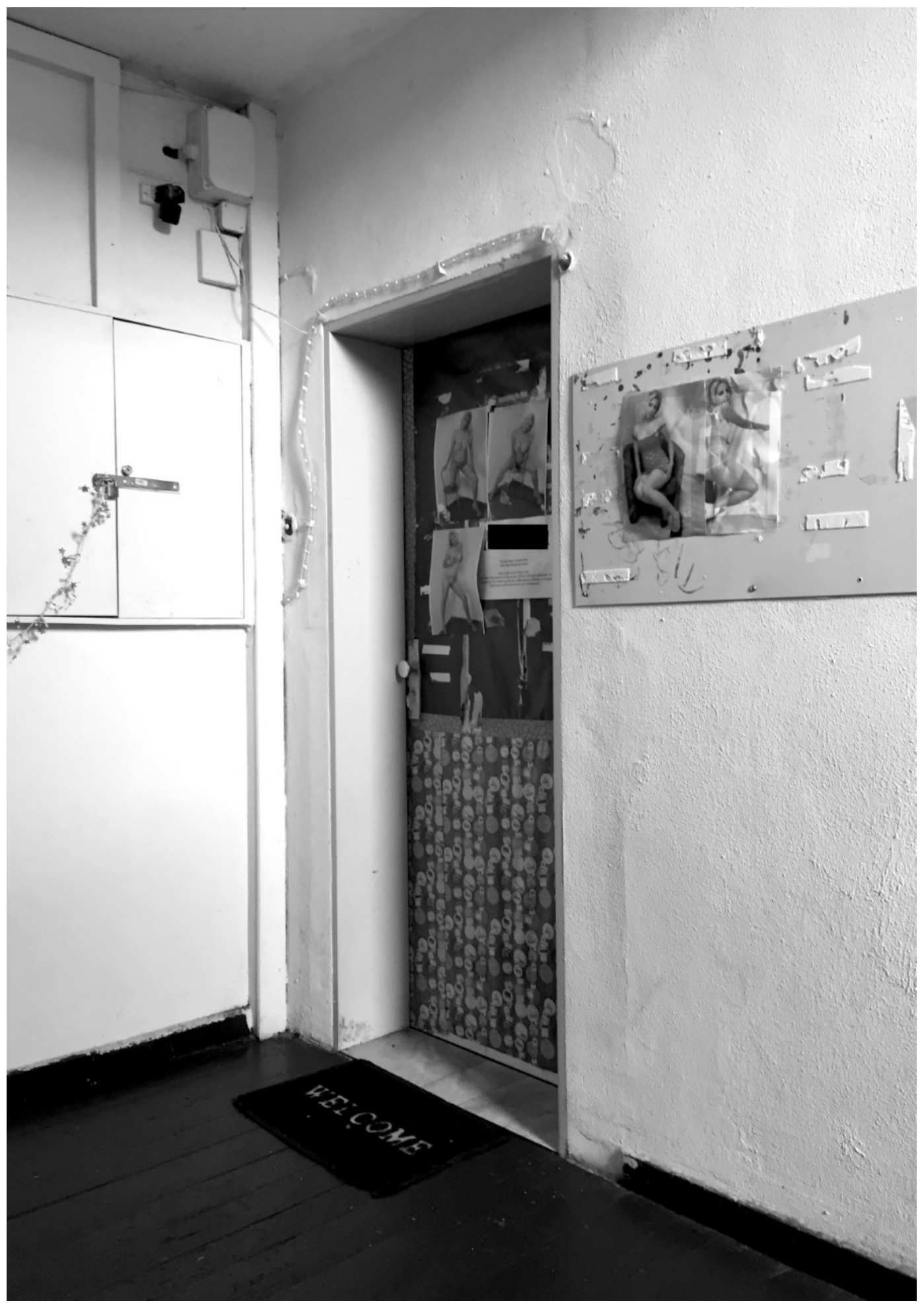

Fig. 2 Entering the apartments. Image by author, 2015.

In noting, explaining, complaining, or commenting on the absence or presence of basic perceivable stimuli, such as light, heat or odors, the officers were essentially 
expressing their 'gut feelings,' i.e., visceral affective reactions to perceivable absences and presences of highly particular properties. By transforming the sensuous into the sensational, the officers were enacting the normative. They performed their 'common sense' of what was the 'normal' and the 'right' reaction to the deviant and the morally wrong. As the officers acted 'naturally' in accordance with the perceived situation, these reactions could be termed 'vice policing instincts.' This instinctive form of knowledge is practical and 'embedded in local experience' (Scott 1998, 320). It is part of the vice squad police officers' skill set and resembles Scott's concept of mētis, i.e., 'a wide array of practical skills and acquired intelligence in responding to a constantly changing natural and human environment' (1998, 313). Scott explained:

Any experienced practitioner of a skill or a craft will develop a large repertoire of moves, visual judgements, a sense of touch, or a discriminating gestalt for assessing the work as well as a range of accurate intuitions born of experience that defy being communicated apart from practice (Scott 1998, 329).

These 'instincts' constitute affective forms of knowledge that are, according to Valverde, 'creative, dynamic, hybrid, open-ended' and thus quite characteristic for vice squad policing $(2003,22)$. After all, the world of vice is legally speaking a rather 'shadowy realm' to govern, as 'there is no exhaustive list of indicators of vice, much less a clear checklist of indicators of virtue, order, and decency' (Valverde 2003, 16, 22). Due to the lack of technical knowledge on how and where to draw the boundary, it was merely rational that the vice squad officers applied different forms of knowledge that were instinctive, intuitive, and sensuously affective - thus, they were coming to know the 'milieu' affectively.

\section{'Don't Let the Bedbugs Bite' - Performing Disgust}

During one of the raids I was observing, I was listening to a conversation between the older and raid-experienced Officer Grohl and the younger riot PO Schneider, who accompanied the vice squad's raid in his first years in the field after recently having finished his master's degree. Bonding during a short period of waiting, they stood in the hallway of the raided sex worker's apartment, chatting about bedbugs. The officers did not actually see or find a bedbug, but they conjured the idea of a bedbug infestation while standing in a sex worker's apartment, waiting for their squad leader to finish his writing. Officer Grohl said, 'In the case of a bedbug infestation, you're supposed to heat the room to more than 60 degrees for some hours. You're bringing home bedbugs real easy.' And the younger Officer Schneider replied, 'With your shoes and stuff?' Grohl said, 'Yeah.' 'So what will you do about this later?,' asked Officer Schneider, and Grohl said, 'I'll get rid of all my clothes and put them in the laundry.' 'And your shoes?', asked Schneider. 'Disinfect them,' said Grohl. 'And theoretically,' Schneider continued his inquiry, 'you have to do that every time?' Grohl replied, 'For our controls, I always carry another set of clothes. If I know I have a control, I always bring a change. It's totally 
gross.' He laughed. Schneider then said, 'You always believe that it won't be that bad. But now, I really feel it itching everywhere. I never put that many thoughts into it.' And Grohl, still laughing, said to him, 'It's super gross. Bed bugs - Google it, it's awesome!'

Officer Fuchs approached the two officers. Apparently, he was finished. Fuchs asked the officers where the sex worker had gone. Standing in the hallway, they were looking into the kitchen, just in time to see her picking something up from the floor. Bending down, her butt was showing. Grohl said, 'There she is.' And the three of them were looking at her and making grimaces, i.e., squinting their eyes and making noises such as 'mmh' and 'ugh' by which they were expressing that they find the sight of her back repulsive. Fuchs asked for her telephone number (field notes, 2015).

Apparently, the need to address the issue of bedbugs was not the result of tangible (raid) experience but it was brought up by Grohl because he recently read an article on the topic. Nonetheless, it was not accidental that the officers chose this topic, for them it appeared related to the setting they found themselves in. Simultaneously, they enacted the properties of that setting as disgusting, dirty, and potentially infested. This enactment was not limited to verbal expressions, but also bodily enacted: a suspicious look at the carpet, an extra set of clothes carefully washed and disinfected after the raid, or the sensation of itching on Officer Schneider's skin. When the raid that day was interrupted by the event of taking someone back to the station, the first thing the officers did was announce that their hands needed to be washed; they washed them immediately. Likewise, at the beginning of the raid, Officer Schneider jokingly asked everyone if all of them remembered to take rubber gloves.

The bedbugs discussion illustrates how the feeling of disgust materialized in the practices of the officers. Disgust was not only performative but also functional. Imogen Tyler argued in this respect that the performance of disgust in the realm of politics is linked to the processes of making abject. Performing disgust unfolds in its boundary-making capacity, i.e., it is used in the endeavor of ordering in the sense of establishing and re-establishing the boundaries between those below and those above. Practicing and performing disgust affirmed the moral order that the vice squad and the world of vices constituted. As the officers were careful 'not to touch anything,' protecting their skin with rubber gloves, washing their hands, separating 'raid clothes' from 'normal workday clothes,' and conjuring the horrors of a bedbug infestation, they distanced themselves from the 'milieu' in regard to its dirty and disgusting properties. Practices of distancing occurred in the proximity of directly interacting with the 'milieu' during the raid.

Disgust is described as a 'moral sentiment', a direct expression of the moral order it is situated in (Throop 2012, 150). Disgust is also linked to the governmental mode of abjection (Tyler 2013), and as Ahmed argued, disgust 'involves a relationship of touch and proximity [... and] [t]hat contact is felt as an unpleasant intensi- 
ty: it is $[\ldots]$ the proximity of the object to the body [that] is felt as offensive' (Ahmed 2004, 85; see also Walby \& Spencer 2011, 114). The performance of disgust mediates, makes, and maintains a moral order. Within the practice realm of the raid, performing disgust affirmed the boundaries between the 'aboveness' of the vice squad and the 'belowness' of the 'milieu' as the world of vices.

However, the 'aboveness' and 'belowness' were, in this study, effects stemming from practice. None of the participating vice squad officers in this ethnographic exploration would actively articulate themselves as being on 'higher' moral grounds, above their subjects of control, the sex workers. When the officers talked about sex workers in interviews conducted at the police station, they were decidedly compassionate. The relation between the vice squad and the 'world of vices' was neither dialectical nor one-directional - yet diving into this complex relationship would exceed the scope of this paper. However, most officers saw the red-light 'milieu' as a rather 'shadowy realm' to govern, an underworld that was difficult to know and understand. The policing of vices might differ from other research on police morality (e.g. Feldman 2018; Herbert 1996; Muir 1977), but it should be stressed that the police officers in this study did not make their moral judgements out of thin air. Rather, and similarly to what Johnson argued in regard to the policing of sexual offences,

'Public morality' should [...] be seen as a dynamic resource that is used by police officers to reach judgments about the behaviours they police. Police discretion, in this sense, should be seen as the outcome of individual moral decisions made in relation to socially dominant ideas about particular types of conduct (Johnson 2010, 414).

\section{Conclusion}

The moral worlds of policing sex work and performing raids in the red-light 'milieu' are constituted in the making of boundaries through visual, olfactory, somatosensory, and auditory sensations which are to be understood as normative performances, belonging to the realm of morality. Through seeing, demonstrating, and pointing out, the officers were concerned with 'the anomalous which is marked and transposed to a different register of visibility' (Brighenti 2014, 25). The 'police gaze' is thus a decisive factor within the discretionary realm of police officers, and the officers' field of view is affected - what they see, what strikes them, what they notice, and what they need to point out is structured, in fact, by their professional pursuit to look for anything that deviates from the norm (Finstad 2000). Yet it is not only the 'police gaze' that forms and informs practices of discretionary boundary-making, but also the 'police nose,' the 'police ears,' and the 'police touch.' In this regard, Cook and Whowell argued that, for further research on policing practices in their capacities of order- and world-making, it is imperative that we understand how other senses [than vision], such as sound, taste, touch 
and smell, are infused in the production and consumption of 'acceptable' and 'unacceptable' bodies, signs and spaces' $(2011,618)$.

In the ethnographic material presented in this paper, the officers transformed the sensuous into sensations that enacted the normative distinctions between the 'normal' and the 'abnormal,' morally questionable 'milieu.' In the vice squad officers' practices and performances, morals, affects, and sensations came to be understood as deeply intertwined and nearly impossible to separate. As Reichlin emphasizes, 'moral properties are not real properties of the world' $(2012,603)$, but, as has been illustrated, properties being made in an ongoing process and maintained through the repetition of situational performances that make morality in a sensory-affective manner. Morality not simply is but is being done. The vice squad and the 'milieu' were co-constituted in these practices, set in relation to each other and ordered, "aboveness" and "belowness" become properties of particular bodies, objects and spaces' (Ahmed 2004, 89, emphasis in original). The 'milieu' was (co)produced as a space that was dark, odorous, and too hot and inhabited by objects that were indecent, smelly, loose, and vicious. It was a performance on disorder and order, on what is normal and what is not, and thus a deeply political set of practices and processes that explains how order- and boundary-making operates through basic sensations and feelings, of the sensuous, the aesthetic, and the somatic.

\section{Author Bio}

Fulia Leser is a Postdoctoral Research Fellow at Leipzig University and a researcher affiliated with the BMBF-funded project 'Strangers in Their Own Land?' (Leipzig University), the BMBF-funded project 'Beyond the Glass Ceiling' (TU Darmstadt, HAWK Hildesheim/Holzminden/Göttingen), and the DFG-funded project 'Institutionalizing Human Trafficking - A French-German Comparison' (Leipzig University). Leser studied Political Science and Japanese Studies at Waseda University (Japan) and Leipzig University (Germany), where she obtained her PhD degree in 2019. Her research interests relate to understanding the politics of policing and the politics of affects, and further include national security and migration control, nationalism, populism, political ethnography, and state theory. Her $\mathrm{PhD}$ thesis Feeling Blue: Affective rationalities in vice squad policing is an ethnographic study of police raids in the sex work sector that focuses in particular on emotion management techniques in policing agencies. She is also a member of COST Action IS1209 'Comparing European Prostitution Policies: Understanding Scales and Cultures of Governance' (ProsPol).

\section{Funding}

This work was supported by the German Research Council (Deutsche Forschungsgemeinschaft, DFG) and the French National Agency for Research (Agence nationale de la recherché, ANR) under Grant 246481356, 'Institutionalizing Human Trafficking. A French-German Comparison’ (2014-2017). 
Julia Leser - On the Sensory Policing of Vices

\section{Acknowledgements}

I am very grateful to the editors of the special issue and to the anonymous reviewers for their important and constructive comments.

\section{References}

Agustín, L. 2008a. "Sex and the limits of enlightenment: The irrationality of legal regimes to control prostitution." Sexuality Research and Social Policy 5(4): 73-86, https://doi.org/10.1525/srsp.2008.5.4.73

Agustín, L. 2008b. Sex at the margins: migration, labour markets and the rescue industry. London: Zed Books.

Ahmed, S. 2004. The cultural politics of emotion. New York: Routledge.

Ahmed, S. 2017. Living a feminist life. Durham; London: Duke University Press. https://doi.org/10.1215/9780822373377

Banton, M. 1964. The Policeman in the Community. London: Tavisto.

Beek, J. 2016. Producing stateness: police work in Ghana. Leiden; Boston: Brill. https://doi.org/10.1163/9789004334908

Beek, J. 2012. "'There should be no open doors in the police': criminal investigations in northern Ghana as boundary work." The Journal of Modern African Studies 50 (4): 551-72. https://doi.org/10.1017/S0022278X12000353

Bierschenk, T. 2016. "Police and State." In Bradford, B., Jauregui, B., Loader, I., \& Steinberg, J. (Eds.). The SAGE Handbook of Global Policing. London: Sage, 155-78. https://doi.org/10.4135/9781473957923.n10

Bittner, E. 1974. "Florence Nightingale in Pursuit of Willie Sutton: A Theory of the Police." In Jacob, H. (Ed.). The Potential for Reform of Criminal Justice. Beverly Hills: Sage, 17-44.

Bittner, E. 1970. The Functions of the Police in Modern Society: A Review of Background Factors, Current Practices, and Possible Role Models. Chevy Chase: National Institute of Mental Health, Center for Crime and Delinquency.

Bittner, E. 1967. "The police on skid-row: A study of peace keeping." American Sociological Review 32 (5): 699-715. https://doi.org/10.2307/2092019 
Julia Leser - On the Sensory Policing of Vices

Brighenti, A. M. 2014. Visibility in social theory and social research. Basingstoke; New York: Palgrave Macmillan.

Butler, J. 1993. Bodies that matter: On the discursive limits of 'sex.' New York: Routledge.

Clough, P. T. 2007 (Ed.). The Affective Turn. Theorizing the Social. Durham; London: Duke University Press. https://doi.org/10.1215/9780822389606

Cook, I. R., \& Whowell, M. 2011. "Visibility and the Policing of Public Space." Geography Compass 5 (8): 610-22. https://doi.org/10.1111/j.1749-8198.2011.00437.x

Du Gay, P. 1994. "Making up Managers: Bureaucracy, Enterprise and the Liberal Art of Separation.” The British Journal of Sociology 45 (4): 655-74. https://doi.org/10.2307/591888

Ericson, R. V. 1982. Reproducing order: a study of police patrol work. Toronto; Buffalo: University of Toronto Press. https://doi.org/10.3138/9781442679245

Farrell, A., \& Pfeffer, R. 2014. "Policing Human Trafficking: Cultural Blinders and Organizational Barriers." The ANNALS of the American Academy of Political and Social Science 653 (1): 46-64. https://doi.org/10.1177/0002716213515835

Fassin, Didier 2018. "A moral interpretation of police deviance.” In Karpiak, K., \& Garriott, W. C. (Eds.). The anthropology of police. Abingdon; New York: Routledge, 175-187. https://doi.org/10.4324/9781315687759-11

Fassin, D. 2015. "Maintaining Order: The Moral Justifications for Police Practices.” In Fassin, D., Bouagga, Y., Coutant, I., Eideliman, J.-S., Fernandez, F., Fischer, N., Kobelinsky, C., Makaremi, C., Mazouz, S., \& Roux, S. (Eds.). At the Heart of the State: The Moral World of Institutions. London: Pluto Press, 93-116. https://doi.org/10.2307/j.ctt183p5tb

Fassin, D. 2013. Enforcing order: An ethnography of urban policing. Cambridge: Polity Press.

Feldman, G. 2018. The gray zone: Sovereignty, human smuggling, and undercover police investigation in Europe. Stanford University Press. 
Julia Leser - On the Sensory Policing of Vices

Fineman, S. (Ed.). 2000. Emotion in organizations (2nd ed). London; Thousand Oaks: Sage Publications.

Finstad, L. 2000. Politiblikket [The Police Gaze]. Oslo: Pax Forlag.

Foucault, M. [1976] 1978. The History of Sexuality. Volume I: An Introduction. New York: Pantheon Books.

Graham, M. 2002. "Emotional Bureaucracies: Emotions Civil Servants, and Immigrants in the Swedish Welfare State." Ethos 30 (3): 199-226.

https://doi.org/10.1525/eth.2002.30.3.199

Gregg, M., \& Seigworth, G. J. (Eds.) 2010. The Affect Theory Reader. Durham; London: Duke University Press. https://doi.org/10.1215/9780822393047

Gross, H., Frevel, B., \& Dams, C. (Eds.) 2008. Handbuch der Polizeien Deutschlands. Wiesbaden: VS Verlag für Sozialwissenschaften.

Herbert, S. 1996. "Morality in Law Enforcement: Chasing 'Bad Guys' with the Los Angeles Police Department." Law \& Society Review 30 (4): 799-818. https://doi.org/10.2307/3054118

Herzfeld, M. 1992. The social production of indifference: exploring the symbolic roots of Western bureaucracy. Chicago: University of Chicago Press.

Hochschild, A. R. 1983. The managed heart. Berkeley: Berkeley University Press.

Illouz, E., \& Finkelman, S. 2009. "An Odd and Inseparable Couple: Emotion and Rationality in Partner Selection." Theory and Society 38 (4): 401-22. https://doi.org/10.1007/s11186-009-9085-5

Johnson, P. 2012. “The Enforcers of Morality?” In Johnson, P., \& Dalton, D. (Eds.). Policing sex. London; New York: Routledge, 23-37. https://doi.org/10.4324/9780203120736

Johnson, P. 2010. "The Enforcement of Morality: Law, Policing and Sexuality in New South Wales." Australian \& New Zealand Journal of Criminology 43 (3): 399-422.

https://doi.org/10.1375/acri.43.3.399

Kyed, H. M., \& Albrecht, P. 2015. "Introduction: Policing and the politics of order-making on the urban margins." In Albrecht, P., \& Kyed, H. M. (Eds.). Policing and the politics of order-making. Abingdon; New York: Rout- 
Julia Leser - On the Sensory Policing of Vices

ledge, 1-23.

https://doi.org/10.4324/9781315813745-1

Laszczkowski, M., \& Reeves, M. 2015. "Introduction. Affective States-Entanglements, Suspensions, Suspicions.” Social Analysis 59 (4): 1-14. https://doi.org/10.3167/sa.2015.590401

Leser, J. 2018. "Policing the Absence of the Victim: An Ethnography of Raids in Sex Trafficking Operations.” In: Sanders, T., \& Laing, M. (Eds.). Policing the Sex Industry: Protection, Paternalism and Politics. Abingdon, Oxon; New York: Routledge, 109-125. https://doi.org/10.4324/9781315196893-7

Leser, J., Pates, R., \& Dölemeyer, A. 2017. "The Emotional Leviathan - How Street-Level Bureaucrats govern Human Trafficking Victims." Digithum 19: 19-36.

https://doi.org/10.7238/d.v0i19.3088

Lipsky, M. 1980. Street-level Bureaucrats: Dilemmas of the Individual in Public Services. New York: Russell Sage Foundation. https://doi.org/10.2307/1288305

Loyens, K. 2015. "Law Enforcement and Policy alienation: Coping by Labour Inspectors and Federal Police Officers." In Hupe, P., Hill, M., \& Buffat, A. (Eds.). Understanding Street-level Bureaucracy. Bristol; Chicago: Policy Press, 99-114. https://doi.org/10.2307/j.ctt1t89bw0.10

Mainsant, G. 2010. „Du juste usage des émotions.“ Déviance et société 34 (2); 253-65. https://doi.org/10.3917/ds.342.0253

Manning, P. K. 2014. "Ethnographies of Policing." In Reisig, M. D., \& Kane, R. J. (Eds.). The Oxford handbook of police and policing. Oxford; New York: Oxford University Press, 518-47.

Manning, P. K. 2003. Policing Contingencies. Chicago: University of Chicago Press. https://doi.org/10.7208/chicago/9780226503523.001.0001

Mitchell, T. 1991. "The Limits of the State: Beyond Statist Approaches and Their Critics." The American Political Science Review 85: 77-96. https://doi.org/10.1017/S0003055400271451

Muir, W. K. 1977. Police: streetcorner politicians. Chicago: The University of Chicago Press. 
Navaro-Yashin, Y. 2006. "Affect in the civil service: a study of a modern state-system." Postcolonial Studies: Culture, Politics, Economy 9 (3): 281-94. https://doi.org/10.1080/13688790600824997

Passoth, J. H., \& Rowland, N. J. 2010. "Actor-network state: Integrating actor-network theory and state theory." International Sociology 25 (6): 818-41. https://doi.org/10.1177/0268580909351325

Penz, O., \& Sauer, B. 2016. Affektives Kapital: Die Ökonomisierung der Gefühle im Arbeitsleben. Frankfurt, New York: Campus Verlag.

Reckwitz, A. 2012. "Affective Spaces: A praxeological outlook." Rethinking History $16(2): 241-58$.

https://doi.org/10.1080/13642529.2012.681193

Reichlin, M. 2012. „Neuroethics.“ In Fassin, D. (Ed.). A companion to moral anthropology. Hoboken: Wiley-Blackwell, 595-610.

https://doi.org/10.1002/9781118290620.ch33

Reiner, R. 2015. "Revisiting the Classics: Three Seminal Founders of the Study of Policing: Michael Banton, Jerome Skolnick and Egon Bittner." Policing and Society 25 (3): 308-327.

https://doi.org/10.1080/10439463.2015.1013753

Reiner, R. 2010. The politics of the police. Oxford: Oxford University Press. https://doi.org/10.1093/he/9780199283392.001.0001

Schneider, G. L. 2014. Police power and race riots: Urban unrest in Paris and New York. Philadelphia: University of Pennsylvania Press. https://doi.org/10.9783/9780812209860

Scott, J. C. 1998. Seeing Like a State: How Certain Schemes to Improve the Human Condition Have Failed. New Haven: Yale University Press.

Scoular, J. 2015. The Subject of Prostitution: Sex work, Law, and Social Theory. Abingdon; New York: Routledge. https://doi.org/10.4324/9781315778433

Skolnick, J. H. 1966. Justice without Trial: Law Enforcement in Democratic Society. New York: John Wiley.

Stoler, A. L. 2007. “Affective States.” In Nugent, D., \& Vincent, J. (Eds.). A Companion to the Anthropology of Politics. Malden; Oxford; Carlton: Blackwell Publishing, 4-20. https://doi.org/10.1002/9780470693681.ch1 
Julia Leser - On the Sensory Policing of Vices

Throop, C. J. 2012. "Moral Sentiments." In Fassin, D. (Ed.). A companion to moral anthropology. Hoboken: Wiley-Blackwell, 150-68. https://doi.org/10.1002/9781118290620.ch9

Tyler, I. 2013. Revolting Subjects: Social Abjection and Resistance in Neoliberal Britain. London; New York: Zed Books.

Valverde, M. 2003. Law's dream of a common knowledge. Princeton: Princeton University Press.

Walby, K., \& Spencer, D. 2011. "How Emotions Matter to Moral Panics." In Hier, S. P. (Ed.). Moral panic and the politics of anxiety. London: Routledge, 104-17.

Walkowitz, J. 1980. Prostitution and Victorian society: women, class and the state. London: Cambridge University Press. https://doi.org/10.1017/CBO9780511583605

Wetherell, M. 2012. Affect and emotion: a new social science understanding. Los Angeles; London: Sage.

https://doi.org/10.4135/9781446250945 